\title{
Synthesis, spectral characterization, catalytic and biological studies of new Ru(II) carbonyl Schiff base complexes of active amines
}

\author{
Vellalapalayam Vangaiannan Raju', Kugalur Palanisamy Balasubramanian ${ }^{1}$, \\ Chinnasamy Jayabalakrishnan², Vaiapuri Chinnusamy ${ }^{2^{*}}$ \\ ${ }^{1}$ Department of Chemistry, Gobi Arts \& Science College, Gobichettipalayam, India; \\ ${ }^{2}$ PG Department of Chemistry, Sri Ramakrishna Mission Vidyalaya College of Arts \& Science, Coimbatore, India; \\ *Corresponding Author: vchinnusamy@yahoo.com
}

Received 23 December, 2010; revised 22 March, 2011; accepted 10 April, 2011.

\begin{abstract}
The synthesis and characterization of several hexa-coordinated $\mathrm{Ru}(\mathrm{II})$ complexes of the type $[R u(C O)(B)(L)]\left(B=\mathrm{PPh}_{3} / \mathrm{AsPh}_{3} / \mathrm{py} / \mathrm{pip} ; \mathrm{L}=\mathrm{di}-\right.$ basic tetradentate ligand derived from the condensation of isatin with diamines) were reported. IR, electronic, ${ }^{1} \mathrm{H}-\mathrm{NMR},{ }^{31} \mathrm{P}-\mathrm{NMR}$ of the complexes are discussed. An octahedral geometry has been tentatively proposed for all these complexes. The new complexes have been tested for the catalytic activity in the reaction of oxidation of alcohols in the presence of $\mathrm{N}$-methylmorpholine- $\mathrm{N}$-oxide as co-oxidant. The new complexes were also exhibited antimicrobial investigations.
\end{abstract}

Keywords: Ruthenium(II) Complexes; Tetradentate $\mathrm{N}_{2} \mathrm{O}_{2}$ Schiff Base; Characterization; Catalytic

Oxidation; Antimicrobial Activity

\section{INTRODUCTION}

Transition metal complexes with tetradentate Schiff base ligands have been studied as catalyst for a number of organic oxidation and reduction reactions and electro chemical reduction processes $[1,2]$. The accessibility of ruthenium higher oxidation states $[3,4]$ converts them into excellent catalyst for redox reactions. Particularly, metal complexes of ruthenium have demonstrated to be useful laboratory and industrial homogeneous catalysts in the epoxidation of alkenes and oxidation of alcohols using iodosylbenzene, sodium hypochlorite hydrogen peroxide and $\mathrm{N}$-methylmorpholine- $\mathrm{N}$-oxide as oxygen sources [5-8]. Further the oxidation of organic substrates mediated by high valent ruthenium-oxo species evokes much interest in modeling of cytochrome p.450 [9]. Sharpless et al. [10] carried out a yield oriented study of oxidation of cholesterol, geranial etc. catalyzed by ruthenium complexes in the presence of $N$-methylmorpholine- $N$-oxide and $N, N$-dimethylaniline- $N$-oxide. Furthermore, the catalytic activities of ruthenium complexes containing tertiaryphosphine or arsine ligands are well established [11,12]. Tetradentate Schiff base complexes have been employed as catalysts for many reactions and as biological models in understanding the structure of bio molecules and biological process [13,14].

In addition, the chemistry of chelating tetradentate Schiff base ligands with ruthenium has also been extensively studied [15]. This is due to the fact that Schiff bases offer opportunities for inducing substrate chirality, tuning metal centered electronic factors, enhancing solubility and stability and their use as either homogeneous or heterogeneous catalysis [16-18]. The oxidation of primary and secondary alcohols into their corresponding aldehydes and ketones respectively, plays a central role in organic synthesis $[19,20]$. In continuation of our research interest [21] to understand the role of these simple and inexpensive $\mathrm{N}_{2} \mathrm{O}_{2}$ donor Schiff base ligands towards ruthenium, the reaction of Schiff bases derived from isatin and diamines with ruthenium(II) precursors containing $\mathrm{PPh}_{3} / \mathrm{AsPh}_{3} /$ py/pip has been carried out. Thus, the present work describes the results of synthesis, characterization and properties of hexa coordinated $\mathrm{Ru}(\mathrm{II})$ complexes exhibiting a $\mathrm{N}_{2} \mathrm{O}_{2}$ ligating core with their catalytic activity towards oxidation of alcohols in the presence of NMO. Further, the antibacterial activity of the Schiff bases and their ruthenium complexes were examined. The following Schiff bases, derived from the condensation of isatin with ethylenediamine/o-phenylenediamine/propylene diamine (Scheme 1), were used to prepare the new ruthenium (II) complexes. 


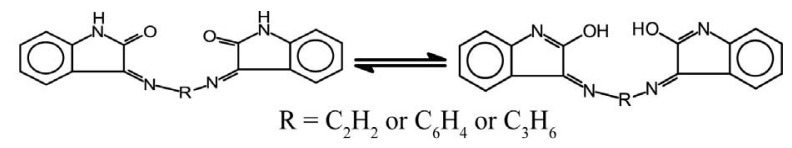

Scheme 1. Keto-enol tautomerism.

\section{EXPERIMENTAL}

\subsection{Materials}

The Schiff bases were prepared by the reported procedure [21,22]. All the reagents used were analytical reagent grade. Solvents were purified and dried according to standard procedures. $\mathrm{RuCl}_{3} \cdot 3 \mathrm{H}_{2} \mathrm{O}$, triphenylphosphine, propylenediamine, ethylenediamine, $o$-phenylenediamine and isatin were purchased from Loba Chemie Pvt Ltd., Bombay, India and were used as such without further purification. [RuHCl$\left.(\mathrm{CO})\left(\mathrm{PPh}_{3}\right)_{3}\right][23],[\mathrm{RuHCl}$ $\left.(\mathrm{CO})(\mathrm{B})\left(\mathrm{PPh}_{3}\right)_{2}\right][24]$ (where $\left.\mathrm{B}=\mathrm{py} / \mathrm{pip}\right)$ and $[\mathrm{RuHCl}$ $(\mathrm{CO})\left(\mathrm{AsPh}_{3}\right)_{3}$ ] [25] were prepared by reported literature methods.

\subsection{Physical Measurements}

The analysis of $\mathrm{C}, \mathrm{H}$ and $\mathrm{N}$ were performed on a Carlo Erba 1160 model 240 Perkin Elmer CHN analyzer, IR spectra were recorded in $\mathrm{KBr}$ pellets in the 4000 $400 \mathrm{~cm}^{-1}$ region in a Jasco 400 plus spectrophotometer. Electronic spectra were recorded in $\mathrm{CH}_{2} \mathrm{Cl}_{2}$ solution with a Hitachi $\mathrm{U}-3210$ spectrophotometer in the range of $800-200 \mathrm{~nm} .{ }^{1} \mathrm{H}-\mathrm{NMR}$ and ${ }^{31} \mathrm{P}-\mathrm{NMR}$ spectra were recorded on a Burker $400 \mathrm{MHz}$ instrument using TMS as an internal reference. Melting points were recorded with Raaga apparatus and were uncorrected.

\subsection{Synthesis of New Carbonyl Complexes of RU(II)}

To a solution of $\left[\mathrm{RuHCl}(\mathrm{CO})\left(\mathrm{EPh}_{3}\right)_{2}(\mathrm{~B})\right][$ where $\mathrm{E}=\mathrm{P}$ or $\left.\mathrm{As} ; \mathrm{B}=\mathrm{PPh}_{3} / \mathrm{py} / \mathrm{pip} / \mathrm{AsPh}_{3}\right](0.1 \mathrm{~g}, 0.1-0.13 \mathrm{mmol})$ in benzene $\left(25 \mathrm{~cm}^{3}\right)$, was added the appropriate Schiff base $(0.039-0.053 \mathrm{~g}, 0.1-0.13 \mathrm{mmol})$. The solution was heated under reflex for $6 \mathrm{hrs}$. Then, it was concentrated to $c a .3 \mathrm{~cm}^{3}$, cooled and new complexes were separated upon addition of small quantity $\left(6 \mathrm{~cm}^{3}\right)$ of light petroleum $\left(60-80^{\circ} \mathrm{C}\right)$. The products were filtered, washed with light petroleum, recrystalysed from $\mathrm{CH}_{2} \mathrm{Cl}_{2} /$ light petroleum mixture and dried in vacuo (yield: 65\% $70 \%$ ). The purity of the complexes was checked by TLC.

\subsection{Catalytic Oxidation}

Catalytic oxidation of alcohols to the corresponding carbonyl compounds by ruthenium(II) carbonyl Schiff base complexes was studied in the presence of NMO as co-oxidant by a typical reaction using the complex $[\mathrm{Ru}(\mathrm{CO})(\mathrm{B}) \mathrm{L}]$ as catalyst, and the alcohol as substrate at a 1:100 molar ratio. For this purpose, a solution of ruthenium complex $(0.01 \mathrm{mmol})$ in $20 \mathrm{~cm}^{3} \mathrm{CH}_{2} \mathrm{Cl}_{2}$ was added to the solution of the substrate $(1 \mathrm{mmol})$ and $\mathrm{NMO}$ ( $3 \mathrm{mmol}$ ) and the mixture was stirred for $3-7 \mathrm{hrs}$ at room temperature. The solvent was evaporated from the mother liquor under reduced pressure and the residue was then extracted with petroleum ether $\left(60^{\circ} \mathrm{C}-80^{\circ} \mathrm{C}\right)$.

\subsection{Antibacterial Activity Studies}

Pathogenic microbials namely Escherichia Coli, Aeromonas hydrophila and Salmonella typhi were used to test the biological potential of the isatin diimine and their carbonyl complexes of ruthenium (II). The antibacterial activities of the complexes were determined by disc diffusion method [26]. The bacteria were cultured in nutrient agar medium in petriplates and used inoculums for the study. The complexes to be tested were dissolved in DMSO to a final concentration of $0.25 \%, 0.5 \%$ and $1 \%$ and soaked in filter paper disc of $5 \mathrm{~mm}$ diameter and of $1 \mathrm{~mm}$ thickness. The disc were placed on the previously seeded plates and incubated at $35 \pm 2{ }^{\circ} \mathrm{C}$ for $24 \mathrm{hrs}$. The diameter of inhibitory zone around each disc was measured after 24 hrs. Streptomycin was used as a standard.

\section{RESULTS AND DISCUSSIONS}

\subsection{Analytical Studies}

Complexes of general formula $[\mathrm{Ru}(\mathrm{CO})(\mathrm{B})(\mathrm{L})]$ (where $\mathrm{B}=\mathrm{PPh}_{3} / \mathrm{AsPh}_{3} / \mathrm{py} / \mathrm{pip} ; \mathrm{L}=$ dibasic tetradentate Schiff bases) were synthesized by the reactions of $\left[\mathrm{RuHCl}(\mathrm{CO})\left(\mathrm{PPh}_{3}\right)_{3}\right],\left[\mathrm{RuHCl}(\mathrm{CO})\left(\mathrm{AsPh}_{3}\right)_{3}\right]$ and $\left[\mathrm{RuHCl}(\mathrm{CO})\left(\mathrm{PPh}_{3}\right)_{2}(\mathrm{~B})\right]$ (where $\mathrm{B}=\mathrm{py} / \mathrm{pip}$ ) with the respective tetradentate Schiff bases (Scheme 2) in a 1:1 molar ratio in benzene.

The analytical data for the new complexes agree well with the proposed molecular formula as given in Table 1. In all the reactions it has been observed that the Schiff bases behave as a dibasic tetratentate ligands by substituting the chloride ion, hydride ion and two triphenylphosphine/arsine groups from each mole of the starting complexes to form the mono nuclear complexes. These observations indicate a more labile nature for the Ru-P bond compared to the $\mathrm{Ru}-\mathrm{N}$ bond of the heterocyclic nitrogen bases in these complexes. The difference in the strength of Ru-P/As and Ru-N bonds may be explained as due to the better $\sigma$ donation ability of the nitrogen bases compared to that of triphenylphosphine/ arsine. The Schiff base ruthenium(II) complexes are highly colored, stable to air and light and soluble in chloroform, methylene chloride, benzene and DMSO.

\subsection{I.R. Spectra}

The most important IR bands are presented and as- 
signed in Table 2. The bands appearing at $1740-1715$ $\mathrm{cm}^{-1}$ and $1652-1619 \mathrm{~cm}^{-1}$ in the ligand spectra were assigned to stretching vibration modes of $\mathrm{C}=\mathrm{O}$ and $\mathrm{C}=$ $\mathrm{N}$ respectively. All the bands assigned to stretching vibration modes in the free ligands changed in the spectra of metal complexes. New bands recorded at $1599-1583$ $\mathrm{cm}^{-1}$ and $1637-1600 \mathrm{~cm}^{-1}$ vibration modes respectively suggest the enolisation of the $\mathrm{NH}$ group of isatin and coordination through the oxygen of the C-O group [21, 27]. The formation of the Ru-O and Ru-N bands is further supported by the appearance of $v_{\mathrm{M}-\mathrm{O}}$ and $v_{\mathrm{M}-\mathrm{N}}$ band in the regions $576-541 \mathrm{~cm}^{-1}$ and $492-475 \mathrm{~cm}^{-1}$ respec-

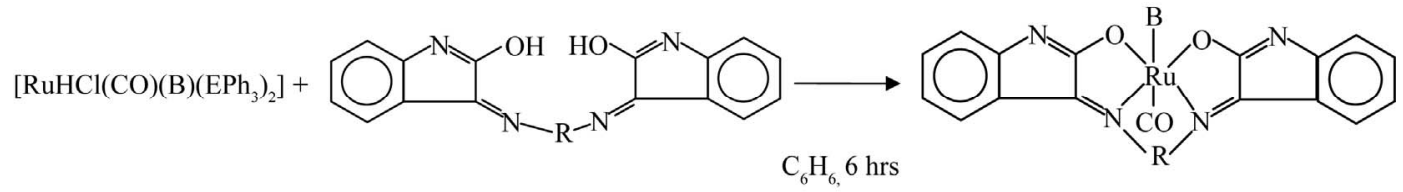

Scheme 2. Preparation of new Ru(II) Schiff base complexes.

Table 1. Analytical data of new $\mathrm{Ru}(\mathrm{II})$ complexes.

\begin{tabular}{cccccc}
\hline Complex & $\mathrm{Mp}\left({ }^{\circ} \mathrm{C}\right)$ & Yield $(\%)$ & \multicolumn{3}{c}{ Calculated(found)\% } \\
\cline { 4 - 6 } & & & $\mathrm{C}$ & $\mathrm{H}$ & $\mathrm{N}$ \\
\hline$\left[\mathrm{Ru}(\mathrm{CO})\left(\mathrm{PPh}_{3}\right)\left(\mathrm{L}^{1}\right)\right]$ & 168 & 80 & $62.80(62.61)$ & $3.81(3.76)$ & $7.92(8.05)$ \\
{$\left[\mathrm{Ru}(\mathrm{CO})\left(\mathrm{AsPh}_{3}\right)\left(\mathrm{L}^{1}\right)\right]$} & 158 & 78 & $59.12(59.25)$ & $3.59(3.67)$ & $7.46(7.52)$ \\
{$\left[\mathrm{Ru}(\mathrm{CO})(\mathrm{py})\left(\mathrm{L}^{1}\right)\right]$} & 143 & 75 & $54.95(55.37)$ & $3.24(3.10)$ & $13.35(12.50)$ \\
{$\left[\mathrm{Ru}(\mathrm{CO})\left(\mathrm{pip}^{1}\left(\mathrm{~L}^{1}\right)\right]\right.$} & 125 & 78 & $54.33(53.57)$ & $4.34(4.01)$ & $13.40(12.67)$ \\
{$\left[\mathrm{Ru}(\mathrm{CO})\left(\mathrm{PPh}_{3}\right)\left(\mathrm{L}^{2}\right)\right]$} & 172 & 75 & $63.24(64.61)$ & $4.02(3.85)$ & $7.77(7.21)$ \\
{$\left[\mathrm{Ru}(\mathrm{CO})\left(\mathrm{AsPh}_{3}\right)\left(\mathrm{L}^{2}\right)\right]$} & 160 & 80 & $59.61(62.01)$ & $3.79(3.51)$ & $7.32(6.56)$ \\
{$\left[\mathrm{Ru}(\mathrm{CO})\left(\mathrm{py}^{2}\right)\left(\mathrm{L}^{2}\right)\right]$} & 145 & 70 & $55.76(57.75)$ & $3.53(3.87)$ & $13.01(12.58)$ \\
{$\left[\mathrm{Ru}(\mathrm{CO})\left(\mathrm{pip}^{2}\right)\left(\mathrm{L}^{2}\right)\right]$} & 130 & 78 & $55.15(55.75)$ & $4.64(4.38)$ & $12.86(11.96)$ \\
{$\left[\mathrm{Ru}(\mathrm{CO})\left(\mathrm{PPh}_{3}\right)\left(\mathrm{L}^{3}\right)\right]$} & 157 & 80 & $65.16(66.18)$ & $3.58(3.85)$ & $7.41(7.58)$ \\
{$\left[\mathrm{Ru}(\mathrm{CO})(\mathrm{AsPh})\left(\mathrm{L}^{3}\right)\right]$} & 142 & 76 & $61.57(62.75)$ & $3.38(3.15)$ & $7.00(6.91)$ \\
{$\left[\mathrm{Ru}(\mathrm{CO})(\mathrm{py})\left(\mathrm{L}^{3}\right)\right]$} & 137 & 75 & $58.74(59.62)$ & $2.97(3.03)$ & $12.24(11.56)$ \\
{$\left[\mathrm{Ru}(\mathrm{CO})\left(\mathrm{pip}^{3}\right)\left(\mathrm{L}^{3}\right)\right]$} & 125 & 75 & $58.13(57.67)$ & $3.98(3.87)$ & $12.11(11.91)$ \\
\hline
\end{tabular}

Table 2. IR and UV - Visible Spectral data for the ligands and new Ru(II) complexes.

\begin{tabular}{|c|c|c|c|c|c|c|}
\hline Complex & $v_{(\mathrm{C}=\mathrm{N})}$ & $v_{(\mathrm{C}=0)}$ & $v_{(\mathrm{C}-\mathrm{O})}$ & $v_{(\mathrm{M}-\mathrm{N})}$ & $v_{(\mathrm{M}-\mathrm{O})}$ & $\lambda_{\max }$ \\
\hline $\mathrm{HL}^{1}$ & 1619 & 1720 & - & & & \\
\hline$\left[\mathrm{Ru}(\mathrm{CO})\left(\mathrm{PPh}_{3}\right)\left(\mathrm{L}^{1}\right)\right]$ & 1620 & - & 1585 & 475 & 541 & $246,320,360,600$ \\
\hline$\left[\mathrm{Ru}(\mathrm{CO})\left(\mathrm{AsPh}_{3}\right)\left(\mathrm{L}^{1}\right)\right]$ & 1628 & - & 1583 & 480 & 547 & $250,320,362,590$ \\
\hline$\left[\operatorname{Ru}(\mathrm{CO})(\mathrm{py})\left(\mathrm{L}^{1}\right)\right]$ & 1600 & - & 1590 & 482 & 562 & $248,316,368,593$ \\
\hline$\left[\operatorname{Ru}(\mathrm{CO})(\mathrm{pip})\left(\mathrm{L}^{1}\right)\right]$ & 1637 & - & 1583 & 488 & 576 & $246,315,368,598$ \\
\hline $\mathrm{HL}^{2}$ & 1652 & 1715 & - & & & \\
\hline$\left[\mathrm{Ru}(\mathrm{CO})\left(\mathrm{PPh}_{3}\right)\left(\mathrm{L}^{2}\right)\right]$ & 1636 & - & 1589 & 487 & 560 & $246,315,568$ \\
\hline$\left[\mathrm{Ru}(\mathrm{CO})\left(\mathrm{AsPh}_{3}\right)\left(\mathrm{L}^{2}\right)\right]$ & 1622 & - & 1597 & 490 & 570 & $248,368,408$ \\
\hline$\left[\operatorname{Ru}(\mathrm{CO})(\mathrm{py})\left(\mathrm{L}^{2}\right)\right]$ & 1628 & - & 1599 & 492 & 575 & $248,316,463,590$ \\
\hline$\left[\mathrm{Ru}(\mathrm{CO})(\mathrm{pip})\left(\mathrm{L}^{2}\right)\right]$ & 1630 & - & 1585 & 479 & 547 & $250,350,403$ \\
\hline $\mathrm{HL}^{3}$ & 1630 & 1740 & - & & & \\
\hline$\left[\mathrm{Ru}(\mathrm{CO})\left(\mathrm{PPh}_{3}\right)\left(\mathrm{L}^{3}\right)\right]$ & 1607 & - & 1587 & 476 & 550 & $248,318,550$ \\
\hline$\left[\mathrm{Ru}(\mathrm{CO})\left(\mathrm{AsPh}_{3}\right)\left(\mathrm{L}^{3}\right)\right]$ & 1615 & - & 1592 & 490 & 570 & $248,325,563$ \\
\hline$\left[\mathrm{Ru}(\mathrm{CO})(\mathrm{py})\left(\mathrm{L}^{3}\right)\right]$ & 1603 & - & 1590 & 486 & 568 & $246,313,569,600$ \\
\hline$\left[\mathrm{Ru}(\mathrm{CO})(\mathrm{pip})\left(\mathrm{L}^{3}\right)\right]$ & 1600 & - & 1588 & 482 & 571 & $246,320,350,596$ \\
\hline
\end{tabular}


tively in the spectra of the chelates $[21,28,29]$. The most important conclusion drawn from the infrared spectral evidence is that the diamine bis(isatin) Schiff base ligand is acting as chelating agent towards the central metal ion as dibasic ONNO tetradentate ligand, via the two coordinating sites of nitrogen atoms and two negatively charged oxygen atoms of isatin residues forming fivemembered chelating rings [30]. In addition, other characteristic bands due to $\mathrm{PPh}_{3}$ and $\mathrm{AsPh}_{3}$ are also present around $1438 \mathrm{~cm}^{-1}$ [31], in the spectra of Schiff base complexes. A medium intensity band is observed in the $1020 \mathrm{~cm}^{-1}$ region, characteristics of the coordinated pyridine or piperidine [21,32]. In all the ruthenium complexes the band due to terminally coordinated $\mathrm{C} \equiv \mathrm{O}$ group appeared at $1900-1944 \mathrm{~cm}^{-1}$ [33].

\subsection{Electronic Spectra}

The electronic spectra of all the complexes in dichloromethane showed three to four bands in the region 246 - $600 \mathrm{~nm}$. All the Schiff base ruthenium complexes are diamagnetic, indicating the presence of ruthenium in the +2 oxidation state. The ground state of ruthenium(II) in an octahedral environment is ${ }^{1} \mathrm{~A}_{1 \mathrm{~g}}$ from the $\mathrm{t}^{6}{ }_{2 \mathrm{~g}}$ configuration and excited states corresponding to the $\mathrm{t}^{5}{ }_{2 \mathrm{~g}} \mathrm{e}_{\mathrm{g}}{ }_{\mathrm{g}}$ configurations are ${ }^{3} \mathrm{~T}_{1 \mathrm{~g}},{ }^{3} \mathrm{~T}_{2 \mathrm{~g}},{ }^{1} \mathrm{~T}_{1 \mathrm{~g}}$ and ${ }^{1} \mathrm{~T}_{2 \mathrm{~g}}$. Hence four bands corresponding to the transition ${ }^{1} \mathrm{~A}_{1 \mathrm{~g}} \rightarrow{ }^{3} \mathrm{~T}_{1 \mathrm{~g}},{ }^{1} \mathrm{~A}_{1 \mathrm{~g}}$ $\rightarrow{ }^{3} \mathrm{~T}_{2 \mathrm{~g}},{ }^{1} \mathrm{~A}_{1} \mathrm{~g} \rightarrow{ }^{3} \mathrm{~T}_{1 \mathrm{~g}}$ and ${ }^{1} \mathrm{~A}_{1 \mathrm{~g}} \rightarrow{ }^{1} \mathrm{~T}_{2 \mathrm{~g}}$ are possible in the order of increasing energy. The bands around $600-550$ $\mathrm{nm}$ and $463-403 \mathrm{~nm}$ are assigned to ${ }^{1} \mathrm{~A}_{1 \mathrm{~g}} \rightarrow{ }^{1} \mathrm{~T}_{1 \mathrm{~g}}[34,35]$ and the charge transfer reactions respectively are listed in Table 2. The charge transfer bands observed in all the complexes due to $\mathrm{M} \rightarrow \mathrm{L}$ transitions are possible in the visible region [36-38]. Moreover the presence of carbonyl, triphenylphosphine/arsine and heterocyclic bases as ligands, which are capable of producing strong ligand field in $\mathrm{e}_{\mathrm{g}}{ }^{*}$ which is relatively higher energy levels. This band has been assigned to the charge-transfer transition arising from the excitation of an electron from the metal $\mathrm{t}_{2 \mathrm{~g}}$ level to the unfilled molecular orbital's derived from the $\mathrm{e}_{\mathrm{g}}{ }^{*}$ level of the ligands should appear in the relatively high energy region compared to those due to $t_{2 g} \rightarrow \mathrm{e}_{\mathrm{g}}{ }^{*}$ transitions [34-36]. The other high energy bands have been designated as $\pi-\pi^{*}$ and $n-\pi^{*}$ transitions for the electrons localized on the azomethine group of Schiff bases [32]. The pattern of the electronic spectra of all the complexes indicated the presence of an octahedral environment around the ruthenium(II) ion, similar to that of other octahedral ruthenium(II) complexes [37].

\section{4. ${ }^{1} \mathrm{H}-\mathrm{NMR}$ Spectra}

The ${ }^{1} \mathrm{H}$ NMR spectra of some complexes were recorded to confirm the bonding of the Schiff base to the ruthenium ion and given in the Table 3. Multiplets are observed around 7.2 - $7.8 \mathrm{ppm}$ in all the complexes and have been assigned to the aromatic protons of triphenylphophine, triphenylarsine, pyridine, piperidine and isatin Schiff base ligands [29]. A singlet appears in the region 1.36 - $1.4 \mathrm{ppm}$ for the methylene protons [39]. In the complexes $\left[\mathrm{Ru}(\mathrm{CO})\left(\mathrm{PPh}_{3}\right)\left(\mathrm{L}^{3}\right)\right]$ and $\left[\mathrm{Ru}(\mathrm{CO})\left(\mathrm{AsPh}_{3}\right)\left(\mathrm{L}^{3}\right)\right]$ an extra singlet was found in the region at $2.05 \mathrm{ppm}$, which has been assigned to the extra methylene group present in the Schiff base. The ${ }^{1} \mathrm{H}$ NMR spectra of the neutral diamagnetic chelates of the type $[\mathrm{Ru}(\mathrm{CO})(\mathrm{B})(\mathrm{L})]$ are similar to those of the ligands, excepting that the signal due to $\mathrm{NH}$ proton of isatin disappears. This proves the deprotonation of NH group upon complexation and supports the above NMR spectral data suggesting that the ligand acts as dibasic tetra dentate chelating agent.

\section{5. ${ }^{31}$ P-NMR Spectra}

The ${ }^{31} \mathrm{P}-\mathrm{NMR}$ spectra for a few of the complexes have been recorded in order to confirm the presence of triphenylphosphine group and to determine the geometry of the complexes (Table 3). The appearance of singlet at $28.78,28.75$ and $28.70 \mathrm{ppm}$ for the complexes $\left[\mathrm{Ru}(\mathrm{CO})\left(\mathrm{PPh}_{3}\right)\left(\mathrm{L}^{1}\right)\right],\left[\mathrm{Ru}(\mathrm{CO})\left(\mathrm{PPh}_{3}\right)\left(\mathrm{L}^{2}\right)\right]$ and

$\left[\mathrm{Ru}(\mathrm{CO})\left(\mathrm{PPh}_{3}\right)\left(\mathrm{L}^{3}\right)\right]$ respectively indicates the presence of one triphenylphosphine group in these complexes.

\subsection{Catalytic Activity of the Complexes}

Catalytic oxidation of primary alcohols and secondary alcohols by the synthesized ruthenium(II) carbonyl Schiff base complex $[\mathrm{Ru}(\mathrm{CO})(\mathrm{B})(\mathrm{L})]$ was carried out in $\mathrm{CH}_{2} \mathrm{Cl}_{2}$ in the presence of NMO. Results of the present investigation suggest that the complex is able to react efficiently with NMO to yield a high valent rutheniumoxo species $[15,40]$ capable of transferring oxygen atom to alcohols. The oxidation of benzylalcohol to benzaldehyde resulted in $89 \%$ yield. Further, the complex effectively catalyzes the oxidation of aliphatic alcohols such as butane-2-ol, to the corresponding ketones effectively and is evident from Table 4. Moreover, the complex effectively catalyzes the oxidation of five and six membered cyclic alcohols to the corresponding ketones with the conversion rates to the extent of $90 \%$ and $82 \%$ respectively. The reaction provides a new environment friendly route to the conversion of alcoholic functions to carbonyl group and water is the only byproduct during the course of the reaction. It has been concluded that the complexes have a better catalytic efficiency in the case of oxidation of primary and secondary alcohols in the presence of NMO.

\subsection{Antibacterial Studies}

The in vitro antibacterial screening of the ligands and 
Table 3. NMR Spectral data of new Ru(II) complexes.

\begin{tabular}{cllc}
\hline S. No. & \multicolumn{1}{c}{ Complex } & \multicolumn{1}{c}{${ }^{1} \mathrm{H}-\mathrm{NMR}$ data $(\mathrm{ppm})$} & ${ }^{31} \mathrm{P}-\mathrm{NMR}$ data $(\mathrm{ppm})$ \\
\hline 1. & {$\left[\mathrm{Ru}(\mathrm{CO})\left(\mathrm{PPh}_{3}\right)\left(\mathrm{L}^{1}\right)\right]$} & $7.2-7.6(\mathrm{Ph}, \mathrm{m}), 1.36\left(\mathrm{~N}-\left(\mathrm{CH}_{2}\right)_{2}, \mathrm{~s}\right)$ & - \\
2. & {$\left[\mathrm{Ru}(\mathrm{CO})\left(\mathrm{AsPh}_{3}\right)\left(\mathrm{L}^{1}\right)\right]$} & $7.3-7.6(\mathrm{Ph}, \mathrm{m}), 1.36\left(\mathrm{~N}-\left(\mathrm{CH}_{2}\right)_{2}, \mathrm{~s}\right)$ & - \\
3. & {$\left[\mathrm{Ru}(\mathrm{CO})(\mathrm{py})\left(\mathrm{L}^{1}\right)\right]$} & $7.2-7.6(\mathrm{Ph}, \mathrm{m}), 1.4\left(\mathrm{~N}-\left(\mathrm{CH}_{2}\right)_{2}, \mathrm{~s}\right)$ & 28.75 \\
4. & {$\left[\mathrm{Ru}(\mathrm{CO})\left(\mathrm{PPh}_{3}\right)\left(\mathrm{L}^{2}\right)\right]$} & $7.3-7.8(\mathrm{Ph}, \mathrm{m})$ & - \\
5. & {$\left[\mathrm{Ru}(\mathrm{CO})\left(\mathrm{AsPh}_{3}\right)\left(\mathrm{L}^{2}\right)\right]$} & $7.2-7.7(\mathrm{Ph}, \mathrm{m})$ & - \\
6. & {$\left[\mathrm{Ru}(\mathrm{CO})\left(\mathrm{pip}^{2}\right)\left(\mathrm{L}^{2}\right)\right]$} & $7.2-7.6(\mathrm{Ph}, \mathrm{m})$ & 28.70 \\
7. & {$\left[\mathrm{Ru}(\mathrm{CO})\left(\mathrm{PPh}_{3}\right)\left(\mathrm{L}^{3}\right)\right]$} & $7.3-7.6(\mathrm{Ph}, \mathrm{m}), 1.36\left(\mathrm{~N}-\left(\mathrm{CH}_{2}\right)_{2}, \mathrm{~s}\right), 2.05\left(\mathrm{CH}_{2}, \mathrm{~s}\right)$ & - \\
8. & {$\left[\mathrm{Ru}(\mathrm{CO})\left(\mathrm{AsPh}_{3}\right)\left(\mathrm{L}^{3}\right)\right]$} & $7.2-7.6(\mathrm{Ph}, \mathrm{m}), 1.36\left(\mathrm{~N}-\left(\mathrm{CH}_{2}\right)_{2}, \mathrm{~s}\right), 2.05\left(\mathrm{CH}_{2}, \mathrm{~s}\right)$ & \\
\hline
\end{tabular}

Table 4. Catalytic oxidation of alcohols by $\mathrm{Ru}(\mathrm{II})$ complexes.

\begin{tabular}{|c|c|c|c|c|}
\hline Complex & Substrate & Product & Yield $^{\mathrm{a}}$ & Turnover $^{\mathrm{b}}$ \\
\hline \multirow{4}{*}[\mathrm{Ru}(\mathrm{CO})(\mathrm{PPh}_{3})(\mathrm{L}^{1})]{} & Benzylalcohol & Benzaldehyde & 76 & 75 \\
\hline & Cyclohexanol & Cyclohexanone & 82 & 80 \\
\hline & Butane-2-ol & Butanone & 84 & 88 \\
\hline & Cyclopentanol & Cyclopentanone & 90 & 92 \\
\hline \multirow{4}{*}[\mathrm{Ru}(\mathrm{CO})(\mathrm{AsPh}_{3})(\mathrm{L}^{1})]{} & Benzylalcohol & Benzaldehyde & 80 & 81 \\
\hline & Cyclohexanol & Cyclohexanone & 82 & 80 \\
\hline & Butane-2-ol & Butanone & 73 & 78 \\
\hline & Cyclopentanol & Cyclopentanone & 89 & 88 \\
\hline \multirow{3}{*}[\mathrm{Ru}(\mathrm{CO})(\mathrm{py})(\mathrm{L}^{1})]{} & Benzylalcohol & Benzaldehyde & 76 & 78 \\
\hline & Cyclohexanol & Cyclohexanone & 83 & 86 \\
\hline & Butane-2-ol & Butanone & 74 & 79 \\
\hline \multirow{5}{*}[\mathrm{Ru}(\mathrm{CO})(\mathrm{pip})(\mathrm{L}^{1})]{} & Cyclopentanol & Cyclopentanone & 90 & 92 \\
\hline & Benzylalcohol & Benzaldehyde & 77 & 79 \\
\hline & Cyclohexanol & Cyclohexanone & 85 & 87 \\
\hline & Butane-2-ol & Butanone & 80 & 84 \\
\hline & Cyclopentanol & Cyclopentanone & 91 & 95 \\
\hline \multirow{3}{*}[\mathrm{Ru}(\mathrm{CO})(\mathrm{PPh}_{3})(\mathrm{L}^{2})]{} & Benzylalcohol & Benzaldehyde & 81 & 85 \\
\hline & Cyclohexanol & Cyclohexanone & 80 & 83 \\
\hline & Butane-2-ol & Butanone & 78 & 87 \\
\hline \multirow{5}{*}[\mathrm{Ru}(\mathrm{CO})(\mathrm{AsPh}_{3})(\mathrm{L}^{2})]{} & Cyclopentanol & Cyclopentanone & 90 & 91 \\
\hline & Benzylalcohol & Benzaldehyde & 82 & 81 \\
\hline & Cyclohexanol & Cyclohexanone & 81 & 85 \\
\hline & Butane-2-ol & Butanone & 72 & 76 \\
\hline & Cyclopentanol & Cyclopentanone & 89 & 86 \\
\hline
\end{tabular}




\begin{tabular}{|c|c|c|c|c|}
\hline \multirow{2}{*}[\mathrm{Ru}(\mathrm{CO})(\mathrm{py})(\mathrm{L}^{2})]{} & Benzylalcohol & Benzaldehyde & 82 & 84 \\
\hline & Cyclohexanol & Cyclohexanone & 80 & 84 \\
\hline \multirow{6}{*}[\mathrm{Ru}(\mathrm{CO})(\mathrm{pip})(\mathrm{L}^{2})]{} & Butane-2-ol & Butanone & 71 & 74 \\
\hline & Cyclopentanol & Cyclopentanone & 90 & 87 \\
\hline & Benzylalcohol & Benzaldehyde & 76 & 79 \\
\hline & Cyclohexanol & Cyclohexanone & 83 & 78 \\
\hline & Butane-2-ol & Butanone & 72 & 75 \\
\hline & Cyclopentanol & Cyclopentanone & 90 & 93 \\
\hline \multirow{3}{*}[\mathrm{Ru}(\mathrm{CO})(\mathrm{PPh}_{3})(\mathrm{L}^{3})]{} & Benzylalcohol & Benzaldehyde & 75 & 78 \\
\hline & Cyclohexanol & Cyclohexanone & 86 & 82 \\
\hline & Butane-2-ol & Butanone & 76 & 80 \\
\hline \multirow{4}{*}[\mathrm{Ru}(\mathrm{CO})(\mathrm{AsPh}_{3})(\mathrm{L}^{3})]{} & Cyclopentanol & Cyclopentanone & 93 & 90 \\
\hline & Benzylalcohol & Benzaldehyde & 73 & 77 \\
\hline & Cyclohexanol & Cyclohexanone & 79 & 80 \\
\hline & Butane-2-ol & Butanone & 70 & 73 \\
\hline \multirow{4}{*}[\mathrm{Ru}(\mathrm{CO})(\mathrm{py})(\mathrm{L}^{3})]{} & Cyclopentanol & Cyclopentanone & 91 & 86 \\
\hline & Benzylalcohol & Benzaldehyde & 75 & 78 \\
\hline & Cyclohexanol & Cyclohexanone & 75 & 79 \\
\hline & Butane-2-ol & Butanone & 72 & 75 \\
\hline \multirow{5}{*}[\mathrm{Ru}(\mathrm{CO})(\mathrm{pip})(\mathrm{L}^{3})]{} & Cyclopentanol & Cyclopentanone & 93 & 80 \\
\hline & Benzylalcohol & Benzaldehyde & 67 & 70 \\
\hline & Cyclohexanol & Cyclohexanone & 81 & 80 \\
\hline & Butane-2-ol & Butanone & 78 & 81 \\
\hline & Cyclopentanol & Cyclopentanone & 91 & 86 \\
\hline
\end{tabular}

their ruthenium complexes have been carried out against Escherichia Coli, Aeromonas hydrophila and Salmonella typhi using a nutrient agar medium by disc diffusion method. The results (Table 5) showed the complexes exhibit moderate activity against Escherichia Coli, Aeromonas hydrophila and Salmonella typhi. The toxicity of ruthenium chelates increases on increasing the concentration [41]. The increase in the antibacterial activity of metal chelates may be due to the effect of the metal ion on the normal cell process. A possible mode of the toxicity increase may be considered in light of Tweeds chelation theory [42]. Chelation considerably reduces the polarity of the metal ion because of partial sharing of its positive charge with the donor groups and possible $\pi$ electron delocalization over the whole chelate ring. Such chelation could enhance the lipophilic character of the central metal atom, which subsequently favors its per- meation through the lipid layers of cell membrane. Furthermore, the mode of action of the compounds may involve in the formation of a hydrogen bond through the azomethine $(>\mathrm{C}=\mathrm{N})$ group with the active centers of cell constituents, resulting in interference with the normal cell processes [42]. Though the complexes possess activity, it could not reach the effectiveness of the standard drug streptomycin. The variation in the effectiveness of the different compounds against different organisms depend either on the impermeability of the cells of the microbes or differences in ribosomes of microbial cells $[40,41]$.

Based on the analytical, spectral (IR, electronic, ${ }^{1} \mathrm{H}$ NMR and ${ }^{31} \mathrm{P}-\mathrm{NMR}$ ) data, Scheme 3 octahedral structure has been tentatively proposed for all the new carbonyl Schiff base complexes of ruthenium (II). 
Table 5. Antibacterial activity of ligands and $\mathrm{Ru}(\mathrm{II})$ complexes (diameter of inhibition zones-mm).

\begin{tabular}{|c|c|c|c|c|c|c|c|c|c|}
\hline \multirow{2}{*}{ Ligand/Complex } & \multicolumn{3}{|c|}{ Escherichia coli } & \multicolumn{3}{|c|}{ Aeromonas hydrophila } & \multicolumn{3}{|c|}{ Salmonella typhi } \\
\hline & $0.25 \%$ & $0.5 \%$ & $1.0 \%$ & $0.25 \%$ & $0.5 \%$ & $1.0 \%$ & $0.25 \%$ & $0.5 \%$ & $1.0 \%$ \\
\hline $\mathrm{L}^{1}$ & 10 & 11 & 13 & 11 & 12 & 13 & 9 & 12 & 13 \\
\hline$\left[\mathrm{Ru}(\mathrm{CO})\left(\mathrm{PPh}_{3}\right)\left(\mathrm{L}^{1}\right)\right]$ & 12 & 14 & 16 & 14 & 17 & 18 & 13 & 16 & 20 \\
\hline$\left[\mathrm{Ru}(\mathrm{CO})\left(\mathrm{AsPh}_{3}\right)\left(\mathrm{L}^{1}\right)\right]$ & 11 & 15 & 17 & 12 & 16 & 20 & 14 & 17 & 21 \\
\hline$\left[\mathrm{Ru}(\mathrm{CO})(\mathrm{py})\left(\mathrm{L}^{1}\right)\right]$ & 14 & 16 & 20 & 13 & 17 & 19 & 15 & 17 & 20 \\
\hline$\left[\mathrm{Ru}(\mathrm{CO})(\mathrm{pip})\left(\mathrm{L}^{1}\right)\right]$ & 16 & 18 & 20 & 13 & 17 & 19 & 15 & 18 & 20 \\
\hline $\mathrm{L}^{2}$ & 10 & 12 & 14 & 9 & 12 & 15 & 10 & 11 & 14 \\
\hline$\left[\mathrm{Ru}(\mathrm{CO})\left(\mathrm{PPh}_{3}\right)\left(\mathrm{L}^{2}\right)\right]$ & 12 & 15 & 19 & 11 & 16 & 18 & 12 & 18 & 20 \\
\hline$\left[\mathrm{Ru}(\mathrm{CO})\left(\mathrm{AsPh}_{3}\right)\left(\mathrm{L}^{2}\right)\right]$ & 15 & 18 & 21 & 12 & 18 & 21 & 14 & 15 & 18 \\
\hline$\left[\mathrm{Ru}(\mathrm{CO})(\mathrm{py})\left(\mathrm{L}^{2}\right)\right]$ & 14 & 16 & 19 & 14 & 19 & 20 & 18 & 20 & 21 \\
\hline$\left[\mathrm{Ru}(\mathrm{CO})(\mathrm{pip})\left(\mathrm{L}^{2}\right)\right]$ & 15 & 20 & 21 & 16 & 18 & 21 & 19 & 20 & 21 \\
\hline $\mathrm{L}^{3}$ & 10 & 11 & 13 & 12 & 14 & 15 & 10 & 11 & 14 \\
\hline$\left[\mathrm{Ru}(\mathrm{CO})\left(\mathrm{PPh}_{3}\right)\left(\mathrm{L}^{3}\right)\right]$ & 12 & 14 & 17 & 14 & 16 & 18 & 15 & 18 & 20 \\
\hline$\left[\mathrm{Ru}(\mathrm{CO})\left(\mathrm{AsPh}_{3}\right)\left(\mathrm{L}^{3}\right)\right]$ & 14 & 18 & 20 & 15 & 18 & 20 & 17 & 18 & 21 \\
\hline$\left[\mathrm{Ru}(\mathrm{CO})(\mathrm{py})\left(\mathrm{L}^{3}\right)\right]$ & 16 & 17 & 21 & 14 & 17 & 19 & 19 & 22 & 23 \\
\hline$\left[\mathrm{Ru}(\mathrm{CO})(\mathrm{pip})\left(\mathrm{L}^{3}\right)\right]$ & 17 & 18 & 22 & 16 & 18 & 22 & 17 & 19 & 22 \\
\hline Streptomycin & 22 & 23 & 28 & 21 & 37 & 29 & 29 & 21 & 25 \\
\hline
\end{tabular}

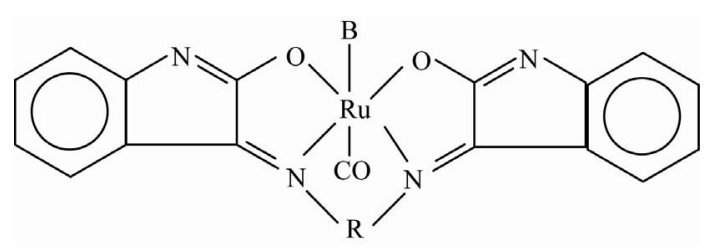

Scheme 3. Structure of New Ru(II) complexes.

\section{CONCLUSIONS}

A new family of carbonyl complexes of ruthenium(II) containing $\mathrm{N}_{2} \mathrm{O}_{2}$ donor Schiff bases incorporating triphenylphosphine/triphenylarsine/pyridine/piperidine ligands were synthesized and characterized. The new complexes were tested as a new and efficient catalyst for the oxidation of primary and secondary alcohols to their corresponding aldehydes and ketones with excellent yields in the presence of $N$-methylmorpholine- $N$-oxide. Further the possible explanations for the mode of action of these complexes against three different microbes are described.

\section{REFERENCES}

[1] Canali, L. and Sherrington, D.C. (1999) Utilization of homogeneous and supported chiral metal (salen) complexes in asymmetric catalysis. Chemical Society Reviews, 28, 85-93. doi:10.1039/a806483k

[2] Isse, A.A., Gennara A. and Viane, E. (1998) Mechanism of the electrochemical reduction of benzylchlorides catalyzed by $\mathrm{Co}(\mathrm{salen})$. Journal of Electroanalytical Chemistry, 444, 241-245.

doi:10.1016/S0022-0728(97)00572-X

[3] Liobet, A., Hodgson D.J. and Meyer, T.J. (1990) Synthesis, structure and redox properties of triaqua (tris (1- pyrazolyl) methan) ruthenium(II) cation. Inorganic Chemistry, 29, 3760-3766. doi: 10.1021/ic00344a023

[4] Liobet, A. (1994) Synthesis, spectral and redox properties of a new series of aqua complexes of Ruthenium (II). Inorganica Chimica Acta, 221, 125-131. doi:10.1016/0020-1693(94)03963-1

[5] Thron, J.R. and Wilkinson, G. (1978) Schiff base complexes of ruthenium(II). Journal of the Chemical Society, Dalton Transactions, 2, 110-115. doi:10.1039/DT9780000110

[6] Katsuki, T. (1995) Catalytic asymmetry oxidation using optically active (salen) Manganese (III) complexes as catalysts. Coordination Chemistry Reviews, 140, 189-214. doi:10.1016/0010-8545(94)01124-T

[7] Claustro, I., G. Abate, Sanchez, E. and Acquaye, J.H. (2003) Synthesis spectroscopic and electrochemical properties of ruthenium-2-(2'-hydroxyphenyl)-benzo- xazole complexes. Crystal structure of [Ru(ter-py) $\mathrm{HPBCl}]$. Inorganica Chimica Acta, 342, 29-36. doi:10.1016/S0020-1693(02)01068-X

[8] Silva, A.R., Freire, C. and Castro, B. (2004) Modulation of the catalytic activity of manganese(III) solen complexes in the epoxidation of styrene: Influence of the oxygen source. New Journal of Chemistry, 28, 253-260. doi:10.1039/b309125b 
[9] Meunier, B. (1992) Metallophorphyrins as versatile catalysts for oxidation reactions and oxidative DNA cleavage. Chemical Review, 92, 1411-1456. doi: $10.1021 / \mathrm{cr} 00014 \mathrm{a} 008$

[10] Sharpless, K.B., Akashi, K. and Osima, K. (1976) Ruthenium catalyzed oxidation of alcohols to aldehydes and ketones by amine-n-oxide. Tetrahedron Letters, 17, 25032506. doi:10.1016/S0040-4039(00)78130-5

[11] Leung, W.H. and Che, C.M. (1989) Oxidation chemistry of Ruthenium-Salon Complexes. Inorganic Chemistry, 28, pp. 4619-4622. doi:10.1021/ic00325a016

[12] Wong, W.K., Chen, X.P., Gao, J.P., Chi, Y.G., Pan, W.X. and Wang, W.Y. (2002) Studies on electronic structures and related properties of complexes $\mathrm{M}(\operatorname{tap})_{3}{ }^{2+}(\mathrm{M}=\mathrm{Fe}, \mathrm{Ru}$, Os) by the DFT method. Journal of the Chemical Society, Dalton Transactions, 1,113-119. doi:10.1039/b105266g

[13] Bhowon, M.G., Wah, L.K. and Narain, R. (1998) Schiff base complexes of Ru (II) and their uses as catalytic oxidants. Polyhydron, 18, 3341-3345.

[14] R. Atkins, G. Brewer, E. Kokot. (1985) Copper (II) and $\mathrm{Ni}(\mathrm{II})$ complexes of unsymmetrical tetra dentate Schiff base ligands. Inorganic Chemistry, 24, 128-134. doi:10.1021/ic00196a003

[15] Khan, M.M.T., Sreelatha, C.H., Mizra, S.A., Ramachandraiah, G. and Abdi, S.H.R. (1998) Synthesis and characterization of $\mathrm{Ru}(\mathrm{V})$ oxo compounds of Schiff base: bis(salicylaldehye) $-O$-phenylenediamine, with appended $\mathrm{Cl}^{-}$, imidazole and 2-methylimidazole: the first complexes of stable oxo-complexes via direct oxygenation. Inorganica Chimica Acta, 154, 103-108. doi:10.1016/S0020-1693(00)85173-7

[16] Clercq, B.D. and Verpoort, F. (2002) Atom transfer radical polymerization of vinyl monomers mediated by Schiff base-Ruthenium-alkylide catalysts and the adventitious effects of water in polymerization with analogous cationic complexes. Macromolecules, 35, 8943-8947. doi:10.1021/ma020307d

[17] Opstal, T. and Verpoort, F. (2002) Ruthenium indenylidene and vinylidene complexes bearing Schiff bases: Potential catalysts in Enol-Ester Synthesis. Synlett, 6, 935-941. doi:10.1055/s-2002-31892

[18] Opstal, T. and Verpoort, F. (2003) Synthesis of highly active Ruthenium indenylidene complexes for atom transfer radical polymerization and ring opening metathesis polymerization. Angewandte Chemie International Edition, 42, 2876-2879. doi:10.1002/anie. 200250840

[19] Sherrington, D.C., Dijksman, A., Arends, I.W.C.E. and Sheldon, R.A. (2001) Polymer immobilized Tempo (PIPO): An efficient catalytic system for environmentally benign oxidation of alcohols. Supported Catalyst and Their Applications, 118-124. doi:10.1039/9781847551962-00118

[20] Venkatachalam, G. and Ramesh, R. (2005) Catalytic transfer hydrogenation of ketones catalysed by ortho metalated ruthenium(III) 2-(aryl azo) phenolate complexes containing triphenylarsine. Tetrahedron Letters, 46, 5215-5218. doi:10.1016/j.tetlet.2005.05.116

[21] Balasubramanian, K.P., Raju, V.V. and Chinnusamy, V. (2009) Synthesis, characteristic, catalytic and antimicribial activities of imidazolo substituted benzilidene im- ines with ruthenium(II) complexes. Journal of Indian chemistry Society, 86, 570-576.

[22] Manivannan, S., Prabhakaran, R., Balasubramanian, K.P., Danabal, V., Karvembu, R., Chinnusamy, V. and Natarajan, K. (2007) Synthesis, spectral, electrochemical and catalytic studies of new $\mathrm{Ru}(\mathrm{III})$ tetra dentate Schiff base complexes. Organic Chemistry, 21, 952-957. doi:10.1002/aoc. 1318

[23] Parnav, C., Kriza, A., Pop, V. and Udrea, S. (2005) Complexes of tin(IV) and Zirconium(IV) with Schiff bases derived from isatin and diamines. Journal of Indian chemistry Society, 82, 7173.

[24] Kanchanadevi, S., Balasubramanian, K.P. and Chinnusamy, V. (2005) Synthesis, characterisation and catalytic studies of ruthenium(II) Schiff base complexes. Transition Metal Chemistry, 30, 330-333. doi:10.1007/s11243-004-5853-2

[25] Raberto, A., Delgade, S., Lee, W.Y., Choi, S.R. and Jun, M.-J. (1991) The chemistry and catalytic properties of ruthenium and osmium complexes. Part 5. Synthesis of new compounds containing arsine ligands and catalytic activity in the homogeneous hydrogenation of aldehydes. Transition Metal Chemistry, 16, 241-244. doi:10.1007/BF01032844

[26] Raman, N., Kulandaisamy, A. and Jeyasubramanian, K. (2002) Synthesis, spectral, redox and biological studies of some Schiff base copper(II), Nickel(II), cobalt(II), Manganese(II), Zinc(II) and oxovanadium complexes derived from 1-phenyl-2,3dimethyl-4(4 iminopentan-2one)pyrazole-5-one and 2-amino phenol/ 2-amino-thiophenol. Indian Journal of Chemistry, 41, 942-949.

[27] Karvembu, R., Hemalatha, S., Prabhakaran, R. and Natarajan, K. (2003) Synthesis, characterization and catalytic activities of ruthenium complexes containing triphenylphosphine/triphenylarsine and tetra dentate Schiff bases. Inorganic Chemistry Communications, 6, 486-490. doi:10.1016/S1387-7003(03)00021-2

[28] Nakamoto, K. (1971) Infrared and Raman Spectra of Inorganic and coordination compounds. Wiley Interscience, New York.

[29] Dyer, J.R. (1978) Application of absorption spectroscopy of organic compounds. Prentic-Hall, Upper Saddle River.

[30] Hassaan, A.M.A. and Shehat, A.K. (1993) Metal chelates of o-phenylenediaminesbis-isatin Schiff base with $\mathrm{La}$ (III), $\mathrm{Ce}(\mathrm{III}), \mathrm{Th}(\mathrm{IV}), \mathrm{UO}_{2}(\mathrm{II}), \mathrm{Ag}(\mathrm{I})$ and $\mathrm{Hg}(\mathrm{II})$. Synthesis and Reactivity in Inorganic and Metal-Organic Chemistry, 23, 815-823. doi:10.1080/15533179308016863

[31] Danialthangadurai, T., Gowri, M. and Natarajan, K. (2002) Synthesis and characterization of Ru(III) complexes containing monobasic bidentate Schiff bases and their biological activities. Synthesis and Reactivity in Inorganic and Metal-Organic Chemistry, 32, 329-343. doi:10.1081/SIM-120003211

[32] El-Shahawi, M.S. and Shoair, A.F. (2004) Synthesis, spectroscopic characterization, redox properties and catalytic activities of some ruthenium(II) complexes containing aromatic aldehyde and triphenylphosphine or triphenylarsine. Spectrochimica acta Part A Molecular and biomolecular spectroscopy, 60, 121-127.

[33] Balasubramanian, K.P., Karvembu, R., Prabhakaran, R., Chinnusamy, V. and Natarajan, K. (2007) Synthesis, spectral, catalytic and antimicrobial studies of $\mathrm{PPh}_{3} /$ 
$\mathrm{AsPh}_{3}$ complexes of $\mathrm{Ru}(\mathrm{III})$ with dibasic tridentate O,N,S donor ligands. Spectrochimica Acta Part A: Molecular and Biomolecular Spectroscopy, 68, 50-54.

doi:10.1016/i.saa.2006.10.049

[34] Remesh, R. and Sivagamasundari, M. (2003) Synthesis, spectral and anti-fungal activity of Ru(II) mixed ligand complexes. Synthesis and Reactivity in Inorganic and Metal-Organic Chemistry, 33, 899-910. doi:10.1081/SIM-120021656

[35] Natarajan, K., Poddar, R.K. and Agarwala, C.U. (1977) Mixed complexes of Ruthenium (III) and Ruthenium(II) with triphenylphosphine or triphenylarsine and other ligands. Journal of Inorganic and Nuclear Chemistry, 39, 431-435. doi:10.1016/0022-1902(77)80056-0

[36] Lever, A.B.P. (1984) Inorganic Electronic Spectroscopy. 2nd Edition, Elsevier, New York.

[37] Chichak, K., Jacquenard, U. and Branda, N.R. (2002) The construction of (Salophen) Ruthenium(II) assemblies using axial coordination. European Journal of Inorganic Chemistry, 2002, 357-368. doi:10.1002/1099-0682(20022)2002:2<357::AID-EJIC35 7>3.0.CO;2-T

[38] Nareshkumar, K. and Ramesh, R. (2004) Synthesis, characterization, redox property and biological activity of ru-
thenium(II) carbonyl complexes containing $\mathrm{O}, \mathrm{N}$ - donor ligands and heterocyclic bases. Spectrochim Acta A Mol Biomol Spectrosc, 60, 2913-2918.

[39] Jayabalakrisnnan, C. and Natarajan, K. (2002) Ruthenium(II)carbonyl complexes with tridentate Schiff bases and their catalytic activity. Transition Metal Chemistry, 27, 75-79. doi:10.1023/A:1013437203247

[40] Prabhakaran, R., Geetha, A., Thilagavathi, M., Karvembu, R., Krishnan, V., Bertagnolli, H. and Natarajan, K. (2004) Synthesis, characterization, EXAFS investigation and antibacterial activities of new ruthenium (III) complexes containing tetra dentate Schiff base. Journal of Inorganic Biochemistry, 98, 2131-2140. doi:10.1016/j.jinorgbio.2004.09.020

[41] Padmapriya, N., Arunachalam, S.V., Sathya, N., Chinnusamy V. and Jayabalakrishnan, C. (2009) Catalytic and antimicrobial studies of binuclear ruthenium (III) complexes containing bis- $\beta$ diketones. Transition Metal Chemistry, 34, 437-445. doi:10.1007/s11243-009-9214-z

[42] Periasamy, M., Balasubramanian, K.P. and Chinnusamy, V. (2004) Synthesis, characterization and biological activities of Ruthenium(II) Schiff base complexes. Indian Journal of Chemistry, 43, 2132-2136. 